\title{
Survival of the North American strain of viral hemorrhagic septicemia virus (VHSV) in filtered seawater and seawater containing ovarian fluid, crude oil and serum-enriched culture medium
}

\author{
R. M. Kocan ${ }^{1, *}$, P. K. Hershberger ${ }^{1}$, N. E. Elder $^{2}$ \\ ${ }^{1}$ School of Fisheries, Box 355100, University of Washington, Seattle, Washington 98195, USA \\ ${ }^{2}$ Western Fisheries Research Center, Marrowstone Island Field Station, 616 Marrowstone Rd, Nordland, Washington 98358-9633, USA
}

\begin{abstract}
The North American strain of viral hemorrhagic septicemia virus (NA-VHSV) could be recovered for up to $40 \mathrm{~h}$ in natural filtered seawater ( $27 \mathrm{ppt}$ ) with a $50 \%$ loss of infectivity after approximately $10 \mathrm{~h}$ at $15^{\circ} \mathrm{C}$. Addition of $10 \mathrm{ppb}$ North Slope crude oil to the seawater had no effect on virus survival. However, when various concentrations of teleost ovarian fluid were added to seawater, virus could be recovered after $72 \mathrm{~h}$ at $0.01 \%$ ovarian fluid and after $96 \mathrm{~h}$ at $1.0 \%$. When cell culture medium supplemented with $10 \%$ fetal bovine serum was added to the seawater, $100 \%$ of the virus could be recovered for the first $15 \mathrm{~d}$ and $60 \%$ of the virus remained after $36 \mathrm{~d}$. These findings quantify NA-VHSV infectivity in natural seawater and demonstrate that ovarian fluid, which occurs naturally during spawning events, significantly prolongs the survival and infectivity of the virus. The extended stabilization of virus in culture medium supplemented with serum allows for low titer field samples to be collected and transported in an unfrozen state without significant loss of virus titer.
\end{abstract}

KEY WORDS: Viral hemorrhagic septicemia · VHSV · Virus survival $\cdot$ Seawater $\cdot$ Ovarian fluid $\cdot$ Crude oil

Resale or republication not permitted without written consent of the publisher

Water-borne viruses must retain their infectivity sufficiently long for the virus to reach and infect a susceptible host. Controlled laboratory experiments demonstrated that the North American strain of VHSV (NA-VHSV) is transmitted via seawater to nonimmune juvenile herring with virus titers as low as $10^{2} \mathrm{pfu} \mathrm{ml}^{-1}$, resulting in lethal infections after just $1 \mathrm{~h}$ exposure (Kocan et al. 1997). Similar results were obtained by placing infected wild fish into flowing seawater tanks with uninfected herring (authors' unpubl. results). What was not clear from these studies was the dynamics of virus survival in seawater and how chemical and physical factors affected these dynamics.

*E-mail: kocan@fish.washington.edu
During the course of previous field studies we observed a loss of low titer virus during transport of water samples to the laboratory (Hershberger 1999). Attempts to freeze water-born virus in culture medium (Eagle's minimal essential medium $10 \%$ fetal bovine serum, MEM-10) prior to shipping resulted in failure to detect any virus due to loss of infectivity during the freezethaw cycle. The phenomenon of freeze-thaw loss was also observed by Dr James Winton (pers. comm.) for NA-VHSV stock cultures. Consequently, the loss of virus infectivity decreased the probability of our detecting low levels of virus in field-collected water samples, which we knew should be present based on previous laboratory studies (Kocan et al. 1996).

In order to detect water-born virus in their natural seawater environment a study was designed to determine the stability of VHSV under various physical and chemical conditions including filtered natural seawater and seawater supplemented with teleost ovarian fluid, crude oil and culture medium. Exposure of VHSV to crude oil in seawater was carried out because the loss of herring in Prince William Sound, AK, USA, following the 'Exxon Valdez' oil spill was thought to be linked to exposure to trace amounts of oil (Carls et al. 1998).

Methods. The VHS virus used in this study was originally isolated in 1993 from bait herring held in net pens in south central Puget Sound, WA, USA. It was propagated on the epithelioma papulosum cyprini (EPC) cell line (Fijan et al. 1983) cultured in MEM-10 and buffered with Tris. The master stock of virus was passed less than 5 times in cell culture before being frozen in aliquots at $-80^{\circ} \mathrm{C}$. This isolate was shown to be highly pathogenic to nonimmune juvenile herring (Kocan et al. 1997). Working stocks of virus were prepared from frozen pre-titered aliquots $\left(1 \times 10^{8} \mathrm{pfu} \mathrm{ml}^{-1}\right)$ as needed and incubated at $15^{\circ} \mathrm{C}$ in MEM-10. 
Four treatments were used to assess the stability of VHSV in seawater and culture medium: (1) filtered natural seawater, (2) Prudho Bay crude oil-exposed seawater, (3) teleost ovarian fluid in seawater, and (4) serum-enriched culture medium in seawater.

Three $10 \mathrm{ml}$ replicates of each treatment were inoculated with stock virus and incubated at $15^{\circ} \mathrm{C}$. Immediately following inoculation, and at selected intervals, $0.1 \mathrm{ml}$ was sampled from each replicate and inoculated onto polyethylene glycol-treated EPC cell cultures (Batts \& Winton 1989). The cultures were incubated for $7 \mathrm{~d}$ at $15^{\circ} \mathrm{C}$, then evaluated by plaque assay. Virus titers were expressed as plaque-forming units (pfu) per milliliter of fluid.

Filtered natural seawater: Seawater was pumped from $10 \mathrm{~m}$ below the surface of Admiralty Inlet (Puget Sound) near Marrowstone Island (Nordland, WA), filtered to $5 \mu \mathrm{m}$ and sterilized with UV light (Kocan et al. 1997).

Seawater and oil: A seawater-accommodated-fraction of North Slope crude oil was prepared as described by Carls et al. (1998), then virus was added at $6 \times 10^{2} \mathrm{pfu} \mathrm{ml} \mathrm{m}^{-1}$. Petroleum hydrocarbons in the seawater were quantified by total hydrocarbon fluorescence (Mason 1987). Briefly, $50 \mathrm{ml}$ volumes of oiled seawater were extracted with $5 \mathrm{ml}$ of hexane which were excited at $280 \mathrm{~nm}$ and the emission read at $374 \mathrm{~nm}$ with no barrier filter in a Perkin-Elmer Model MPF-2A fluorescence spectrophotometer. The slit width was $10 \mathrm{~nm}$ for both the excitation and emission wave length. The concentrations of extractable hydrocarbons were determined from a standard curve using North Slope crude oil dissolved in hexane. The concentration of hydrocarbons in undiluted crude oil was determined gravimetrically. Fluorescence was directly proportional to hydrocarbon concentration and ranged from 2.3 to $7.5 \mathrm{ng} \mathrm{ml}^{-1}$ (ppb). The oil concentration for this study was 3 to $5 \mathrm{ppb}$, derived from the mean of samples collected on 5 successive days. As with seawater alone, samples were taken for $96 \mathrm{~h}$ to determine virus survival in the presence of oil.

Ovarian fluid: Pooled ovarian fluid from 6 chinook salmon Oncorhynchus tshawytscha was added to filtered seawater at varying concentrations ranging from 0.05 to $1.0 \%$. Three replicates of each ovarian fluidseawater dilution were filtered through a $0.45 \mu \mathrm{m}$ filter, then virus added to give a final concentration of

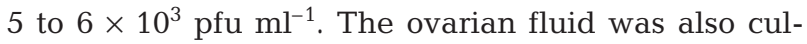
tured on EPC cells to verify that it was not contaminated with virus from the donor fish. Cultures were incubated at $15^{\circ} \mathrm{C}$ and sampled for $96 \mathrm{~h}$.

Enriched culture medium: Double strength Eagle's minimal essential medium $(2 \times$ MEM) was enriched with $20 \%$ fetal bovine serum, mixed 1:1 with viruscontaminated seawater to give a final titer of $5 \times$

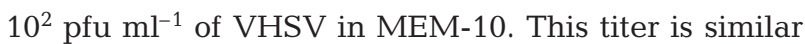
to that found in net pens containing spawning herring (Hershberger et al. 1999). MEM-virus was maintained at $15^{\circ} \mathrm{C}$ and sampled for $35 \mathrm{~d}$ to determine the rate of inactivation.

Results. Stability in seawater and oil: The $50 \%$ survival time for VHSV in seawater and oiled seawater was approximately $10 \mathrm{~h}$ (Fig. 1). After 36 to $40 \mathrm{~h}$ incubation, $10 \%$ of the virus was still recoverable, and trace levels of virus were isolated up to 45-50 h. Virus stability was not affected by the presence of North Slope crude oil in any of the 3 tests and survival curves were similar to seawater alone.

Stability in ovarian fluid and seawater: The presence of teleost ovarian fluid in seawater resulted in stabilization of the virus over the entire range of concentrations tested. Virus was undetectable in seawater controls after $42 \mathrm{~h}$, while virus was detected by plaque assay in all concentrations of ovarian fluid (Fig. 2). Virus was recoverable at low titers after $72 \mathrm{~h}$ in $0.01 \%$ ovarian fluid, while nearly $100 \%$ of VHSV was recovered after $4 \mathrm{~d}$ in $1 \%$ ovarian fluid.

Stability in serum-enriched culture medium and seawater: Storage of virus in serum-enriched MEM-10 resulted in prolonged infectivity of the virus without the need for freezing. Nearly $100 \%$ of the initial VHSV titer was recoverable on cultured cells after $15 \mathrm{~d}$ incubation, and $55 \%$ was recoverable after 36 d (Fig. 3).

Discussion. NA-VHSV was recoverable from filtered seawater for up to $40 \mathrm{~h}$ at $15^{\circ} \mathrm{C}$, with $50 \%$ of the virus being lost after $10 \mathrm{~h}$. Ovarian fluid and serum-enriched culture medium (MEM-10) increased the stability of

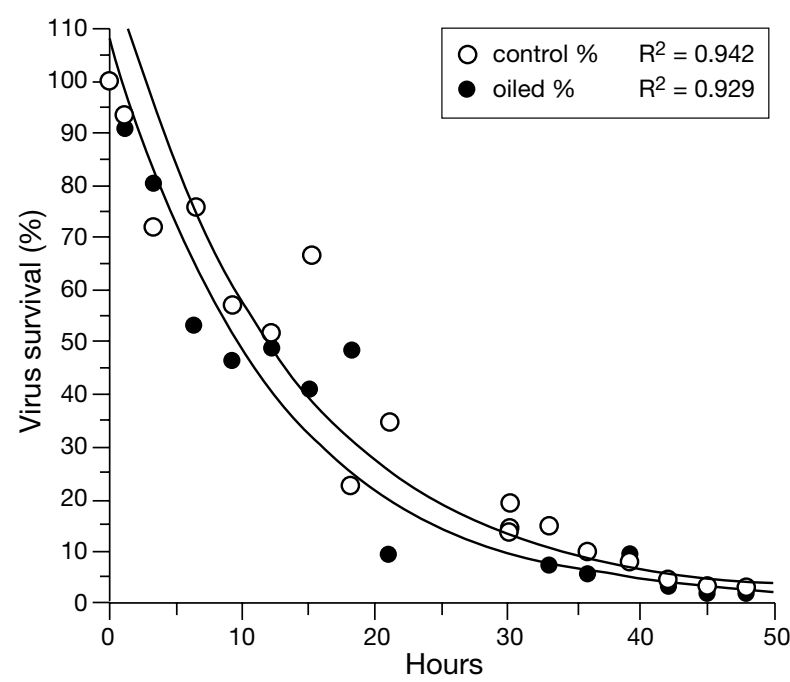

Fig. 1. Survival of NA-VHSV in filtered seawater (27 ppt and $\left.15^{\circ} \mathrm{C}\right)$ and seawater + North Slope crude oil (10 ppb). Initial virus concentration $=6 \times 10^{2} \mathrm{pfu} \mathrm{ml}^{-1}$. Data points represented mean of 3 replicates 


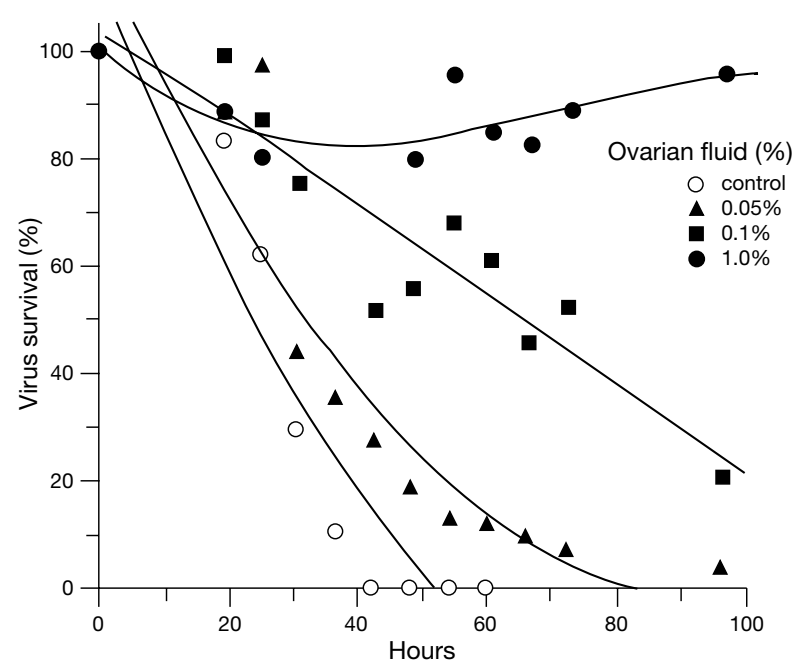

Fig. 2. Survival of the North American strain of VHSV held in $15^{\circ} \mathrm{C}$ seawater supplemented with teleost ovarian fluid. Values $=$ mean of 3 replicates

virus in the unfrozen state, while the presence of crude oil in seawater had no effect on recoverable virus.

There appears to be a significant difference in survival of the NA-VHSV and the European strain (F1) in seawater and freshwater. Winton et al. (1991) reported a 200-fold greater reduction in titer of NA-VHSV over a $24 \mathrm{~h}$ period in freshwater relative to that seen in salt water, while noting that the European strain of VHSV was slightly more stable in salt water than in freshwater. Interestingly, the European (F1) strain of VHSV was reported to survive for over $4 \mathrm{wk}$ in freshwater (Ahne 1982).

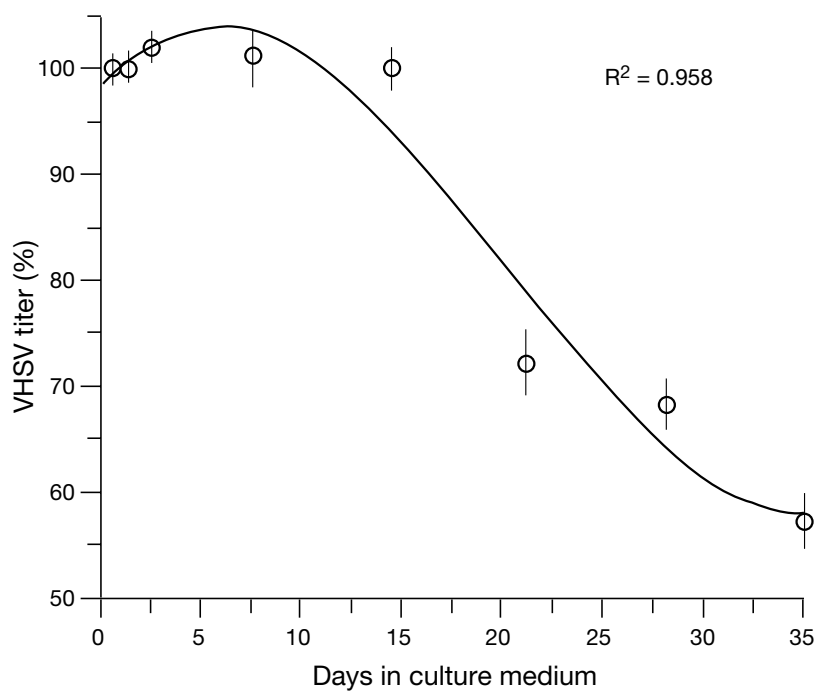

Fig. 3. Survival of NA-VHSV in seawater enriched with culture medium (MEM-10) maintained at $4^{\circ} \mathrm{C}$ for $36 \mathrm{~d}$ (mean $\pm \mathrm{SD}$ )
Previous studies on infectious hematopoietic necrosis virus (IHNV) and VHSV, both rhabdoviruses, have shown that survival is dependent on virus species, strain and physical-chemical conditions of the aqueous medium. IHNV was significantly less stable in seawater than in fresh water (Pietsch \& Amend 1977, Barja et al. 1983) and the addition of serum to the medium significantly extended the survival time of IHNV. This was confirmed by Burke \& Mulcahy (1983), who showed that IHNV was infectious up to 5 wk when held at $4^{\circ} \mathrm{C}$ in ovarian fluid. Experimental data presented by Kocan et al. (1997) showed that even in the absence of protein, survival of VHSV is sufficiently long in seawater to result in the experimental transmission of virus from infected to uninfected individuals. Natural herring spawning events can last from several hours to several days with release of copious amounts of ovarian fluid and milt during this entire period (Breder \& Rosen 1966, Haegele \& Schweigert 1985, authors' pers. obs.). The experimental data presented here demonstrates that even with the dilution of ovarian fluid by tidal change and currents, NA-VHSV could remain infective in the presence of spawning herring for periods significantly longer than in seawater alone.

Previous studies on the transmission of VHSV in net pens used by bait dealers and the spawn-on-kelp (SOK) fishery made it apparent that the ability to isolate viable virus from seawater was essential in order to study the dynamics of virus transmission. Our initial attempts at virus isolation from seawater failed due to the loss of virus when field samples were added to MEM-10 and then frozen and thawed during transport to the laboratory (Hershberger 1999). Loss of rhabdovirus titer during experimental freeze-thaw cycles has been reported previously by Burke \& Mulcahy (1983) and Meyers et al. (1999), who reported that they could not isolate VHSV from frozen tissues of Pacific hake, herring or pollock. They could, however, isolate VHSV from unfrozen tissues of the same species collected at a different time, suggesting that the freezing process may have resulted in a loss of titer. Conversely, de Kinkelin \& Scherrer (1970) reported that the European strain of VHSV (F1) remained stable during successive freeze-thaw cycles if supplemented with serum.

We felt that any loss of virus from low titer field samples would limit our ability to detect the virus. Consequently, we examined the feasibility of placing field-collected seawater samples into serum-enriched medium and transporting them to the laboratory on wet ice, rather than depending on the availability of freezing capability in the field. This technique resulted in no detectable loss of titer after $14 \mathrm{~d}$ and less than $50 \%$ loss after $5 \mathrm{wk}$. Using this technique, we were able to demonstrate that low titers of infectious VHSV 
could be isolated from water both inside and outside SOK net pens, from inside closed purse seines containing herring, and from water in the vicinity of naturally spawning herring (Hershberger et al. 1999).

These findings confirm the potential for NA-VHSV spread in natural seawater, and the techniques used should prove useful as a method of surveying marine waters for the presence of VHSV.

Acknowledgements. The authors acknowledge Dr James Winton, USGS, Seattle, WA, for providing facilities, stock virus, and manuscript editing. This work was supported in part by funds from the 'Exxon Valdez' Trustee Council, project \#98162 and 99162A, and the Washington Dept of Natural Resources, Interagency Agreement \#112451.

\section{LITERATURE CITED}

Ahne W (1982) Vergleichende Untersuchungen über die Stabilität von vier fishpathogenen Viren (VHSV, PFR, SVCV, IPNV). Zbl Vet Med B 29:457-476

Barja JL, Toranzo AE, Lemos ML, Hetrick FM (1983) Influence of water temperature and salinity on the survival of IPN and IHN viruses. Bull Eur Assoc Fish Pathol 3:47-50

Batts W, Winton J (1989) Enhanced detection of infectious hematopoietic necrosis virus and other fish viruses by pretreatment of cell monolayers with polyethylene glycol. J Aquat Anim Health 1:284-290

Breder CM Jr, Rosen DE (1966) Modes of reproduction in fishes. TFH Publications. Crown Publishers, Inc, New York, NY

Burke J, Mulcahy D (1983) Retention of infectious hematopoietic necrosis virus infectivity in fish tissue homogenates and fluids stored at three temperatures. J Fish Dis 6: 543-547

Carls MG, Marty GD, Meyers TR, Thomas SJ, Rice SD (1998) Expression of viral hemorrhagic septicemia virus in prespawning Pacific herring (Clupea pallasi) exposed to weathered crude oil. Can J Fish Aquat Sci 55:2300-2309

Editorial responsibility: Jo-Ann Leong,

Corvallis, Oregon, USA de Kinkelin P, Scherrer R (1970) Le virus d'egtved. Ann Rech Vet 1:17-30

Fijan H, Sulimanovic D, Bearzotti M, Muzinic D, Zwillenberg LO, Chilmonczyk S, Vautherot JF, de Kinkelin P (1983) Some properties of the Epithelioma papulosum cyprini (EPC) cell line from carp Cyprinus carpio. Ann Virol (Inst Pasteur) 134E:207-220

Haegele CW, Schweigert JF (1985) Distribution and characteristics of herring spawning grounds and description of spawning behavior. Can J Fish Aquat Sci 42:39-55

Hershberger PK (1999) Epizootiology of viral hemorrhagic septicemia virus in confined Pacific herring. $\mathrm{PhD}$ dissertation, University of Washington, Seattle

Hershberger PK, Kocan RM, Elder NE, Meyers TR, Winton JR (1999) Epizootiology of viral hemorrhagic septicemia virus in Pacific herring from the spawn-on-kelp fishery in Prince William Sound, Alaska, USA. Dis Aquat Org 37:23-31

Kocan RM, Landolt ML, Winton JR (1996) Investigations of disease factors affecting declines of Pacific herring populations in Prince William Sound. Section II. Laboratory challenge of Pacific herring with and without stressors. Restoration Project Annual Report (Restoration project \# 95320S), Alaska Dept Fish \& Game, Anchorage, AK

Kocan R, Bradley M, Elder N, Meyers T, Batts W, Winton J (1997) North American strain of viral hemorrhagic septicemia virus is highly pathogenic for laboratory-reared Pacific herring. J Aquat Anim Health 9:279-290

Mason RP (1987) A comparison of fluorescence and GC for the determination of petroleum hydrocarbons in mussels. Mar Pollut Bull 18:528-533

Meyers TR, Short S, Lipson K (1999) Isolation of the North American strain of viral hemorrhagic septicemia virus (VHSV) associated with epizootic mortality in two new host species of Alaskan marine fish. Dis Aquat Org 38: 81-86

Pietsch JP, Amend DF (1977) Survival of Infectious Hematopoietic Necrosis virus held under various environmental conditions. J Fish Res Board Can 34:1360-1364

Winton JR, Batts WN, Deering RE, Brunson R, Hopper K, Nishizawa T, Stehr C (1991) Characteristics of the first North American isolates of viral hemorrhagic septicemia virus. In: Proc 2nd international symposium on viruses of lower vertebrates. Oregon State University Press, Corvallis, p 43-50

Submitted: March 25, 2000; Accepted: September 28, 2000 Proofs received from author(s): December 11, 2000 